\title{
Revolutionary Industry and Digital Colonialism
}

\author{
D.E. Wittkower
}

Copyright-based industries have become revolutionary. That is, the machinery of production of digital wares has itself taken on the role of the revolutionary class within the political economy of digital production. The progress of capitalist production in this industry has undermined the conditions of its own possibility, not because it has driven the proletariat to rise against an oppressive system, but because the means of production, through digital media, have simultaneously made communist production possible, and the continued separation of the means of production from the laborer impracticable.

I do admit that there is also certainly a new 'revolutionary class,' at least potentially. While the question about how to characterize such a class is of great importance, my goal here is to put forth an account with an alternate starting point.[1] I hold that we need not thematically address this class, its constitution, or its nascent class-consciousness in order to give a reasonable, though sketchy, account of what has occurred, for this class has emerged as a result of a technological alteration which is itself revolutionary in a way independent of and prior to the constitution of this class as such. Whereas in Marx's view capitalism would produce a revolutionary class which would then have the overthrow of capitalism as a task before it, instead, changes in the means of production have made capitalism as an economic system impossible, and it would seem - with regard to capitalism, at least - that the only classconsciousness requisite of our new 'revolutionary class' is the realization that the revolution is underway, and that capitalism as an economic institution has been replaced by a façade of its former self, propped up only by legal constructions rather than by a firm and originary grounding in the mode of production.

Where the movement of capital was to have undermined the viability of a capitalist society, we see instead that, in the realm of traffic in digital wares, what has occurred is that the conditions for the possibility of capital have been themselves undermined. This, technically, is not a revolution at all, but rather the end of a kind of political-economic "bubble." Nevertheless, as this does not call merely for a market correction, but instead, a socioeconomic correction, the experience which we are undergoing will be one of a revolutionary character, for while the conditions for the possibility of capitalism have been here undermined, there is yet the ongoing attempt to re-create them through a return to primitive accumulation, and, along with it, an attempt to return to a feudal model. The revolution to come, in other words, is the revolt against feudalism, and for this we will, indeed, need a formulation of the emergent revolutionary class, and it will need to attain its class-consciousness. My purpose here, however, is to describe in its origin and effects the 'revolution' - more properly, again, 'correction' - already underway, independent of this class.

\section{Digital Means of Production}

To make this case, I will begin with Marx's Law of the Tendency of the Rate of Profit to Fall, wherein he held that as relative surplus value continued to rise through consolidation, there would be a decrease in the ratio of variable capital to constant capital, which would quite directly imply a decrease in the ratio of profit, a crisis of realization (realization, in this context, being the conversion of the surplus value, created by variable capital, into exchange value within the market), and an increase both in unemployment and in the revolutionary class. He noted 
a number of counteracting forces, the most important for our purposes being the cheapening of the elements of constant capital.

The absolute decrease in variable capital (i.e., the joblessness produced through an ever greater increase of productivity) which was to have brought about the revolutionary moment, was to occur through the relative decrease in variable capital, which is to say, the increased productivity of the worker which accompanies improved machinery, division of labor, and so forth. However, as this process continues, constant capital itself requires less labor-power to produce, and thus the technological means of production undergo the same general cheapening that the price of labour on the market undergoes. After all, if there is a decrease in the rate of profit, this can mean only that each produced item represents an ever smaller amount of reified labor, including raw materials, and most importantly, machinery. As Marx summarized,

The value of the worked-up cotton has not grown in the same proportion as its mass... [and] the same applies to machinery and other fixed capital. In short, the same development which increases the mass of the constant capital in relation to the variable reduces the value of its elements as a result of the increased productivity of labour, and therefore prevents the value of constant capital, although it continually increases, from increasing at the same rate as its material volume. (Marx 1998:234)

Thus, depending on the rate of cheapening and the level of efficiency of means of production within a particular industry, it may be that there is, after all, no relative decrease of variable capital, or possibly even a relative increase of variable capital, concomitant with absolute decrease of both variable and constant capital per commodity produced. If the means of production cheapen alongside variable capital, then, instead of describing the effect as a falling employment rate and therefore a falling rate of profit, we could better describe the effect as an increase in productive power which has no necessary absolute loss of either employment or rate of profit. Further, without this loss of employment or rate of profit, the crisis of realization need never come about, since even the laborer herself will actually be able to purchase the goods brought to market.

This absolute decrease in the labor-value of constant capital per commodity produced, running in parallel with a similar increase in productivity in the realm of variable capital, thus seems to avert a possible crisis of capital; this being one of the reasons why the late Marx - here, much more a cool-headed economist than a Young Hegelian revolutionary - made only the very weak claim implied in his titling the principle here as 'the law of the tendency of the rate of profit to fall.' However, we must take care to look behind the mask of this deus ex machina, for that process which brings an absolute decrease in constant capital in the commodities of a given industry not only restores the viability of consolidated corporations operating in that industry, but also makes the possession of the means of production of that industry ever closer to the grasp of the common wage-earner. The process of the absolute decrease of constant capital, seemingly inevitable for the reasons described above, if unfettered, brings the means of production within the reach of common laborers, at which point they are able to benefit from the use of their own labor-power rather than being forced to bring it to the marketplace, thereby undermining one of the conditions necessary for industrial capital. This possibility was not, as far as I can determine, ever addressed by Marx.[2] The most obvious explanation for this is that the cheapening of machinery which would be necessary to make this a revolutionary effect could not have been foreseen at that time; he would have to have been a mystic or a madman to take seriously the possibility that industrial machinery would be so cheapened that a wage laborer would be able to easily purchase manufacturing capabilities sufficient to compete with capitalist magnates. This possibility has, however, been realized, albeit in a limited scope.

As computational devices have become smaller, more reliable, and more powerful, there has been a significant decline in the absolute constant capital that they represent. At the same time, these machines have been able to perform ever more complex operations in an ever smaller and more manageable time frame, and there has been a great increase in capital investment in the creation of ever more complex and effective operational commands. That is to say, as hardware has improved and cheapened, software has been able to represent a proportionally greater capital investment, and it is the peculiar structure of software that provides the core of the changes I mean to address here.

\section{| Digital Goods and Digital Reproduction}

Contemporary information technologies are remarkable in that any information entered can be stored and 
reproduced with absolute fidelity. Value can be preserved with minimal means of production - access to the information along with available storage space - and with negligible labor. This means, of course, that there is, practically speaking, virtually no valorization at all in the production of any particular iteration of a file or program, although there may have been labor required to order the information in a manner having use-value, to make this information accessible to information technology, and so forth. Furthermore, this is true of digital files of any kind, whether the idea is stated in a directly executable form or not, that is, whether the digital file is a piece of software or a document. (For this reason, I will not differentiate in the following between these kinds of digital files. Both software and documents are similarly losslessly replicable effectively without marginal cost, and, thus, both are equally subject to the analysis here.) The production and reproduction of digital files is in this way akin to the production and reproduction of ideas, excepting that digital files may be of a level of complexity and/or length greater than the human platform can support.

More specifically, digital files are akin to ideas in that, as Thomas Jefferson famously stated, "he who receives an idea from me, receives instruction himself without lessening mine; as he who lights his taper at mine, receives light without darkening me" ([1813] 2000). Given the minimal means of production - having an input of appropriate format in order to allow processing, such as a reasonable person speaking or signing our mother tongue; being of sound mind; not being asleep or distracted or so forth - the reproduction of an idea from an outside source is not only usually accomplished with little effort, but furthermore is actually necessary if any use-value is to be found in that information at all. Digital files are also such that their reproduction is a necessary means for and an integral part of their consumption.[3]

Certain economically valuable expressions have been encouraged due to the great value of the labour-power expended in their initial production and the vanishingly small exchange value of the product thereby produced. The encouragement of this production, through the artificial creation of governmentally enforced scarcity, allowed for the production of ideas which would have little or no use-value to the producer, and, thus, allowed for the production of intellectual commodities, ideas produced for sale rather than personal use, either in the form of a product, such as a book or album, or in the form of machinery (i.e., software).

Now that the means of production of such commodities are greatly and increasingly within public hands due to digital technologies, it has become possible to produce ideas for personal use that are also of value on an industrial scale - that is, as means of production become ever more available, ever more industrial-grade ideas are created for use rather than exchange. Here, if left to their own devices, so to speak, such ideas tend to be shared, rather in the form of a conversation. These non-material means of production, having been invented for personal use, have their reproducibility no longer as a discouragement to their creation, but rather as an accidental bounty, which tends to be given away freely within the community of such unincorporated producers. At this stage in its development, the means of industrial production become themselves revolutionary, bringing about a spontaneous communist economy.

Where means of production are not publicly available, industries must be assured of the potential profitability of any socially beneficial activities we might expect them to perform, but where the public has free access to the means of production the public no longer needs to encourage corporate interests to produce in its stead. It is clearly no longer necessary for our society to guarantee the profitability of the production of a word processor, a web browser, or even an operating system, for fine examples of such machinery may be, and have been, produced by the public without commodification. Similarly, it has now become quite easy and ever more commonplace for people to compose, produce and distribute music and video without commodification, and without governmentally enforced monopoly over the works thus created, which monopoly, regardless, seems to present only an indirect and sometimes almost inconsequential incentive to artists themselves, given the extent to which the current system is biased in favor of distributors rather than artists. [4] Digital technologies have made composition and production of such media considerably easier in any number of ways, from digital cameras and video cameras to software tools. In terms of promotion and distribution, peer-to-peer networks are very efficient distribution networks, and web pages can easily serve the function of promotion, advertisement and distribution, as in for example discussion forums, blogs and personal web pages serving as gateways to other sites and/or materials, content specific artist-operated sites, portals open to direct submission by the public, and portals which make free and public domain works available which might otherwise be difficult or impossible to obtain.

\section{From Wares to Warez}

Formerly, it had been easy to institute property rights over objects which had no natural affinity for them - 
ideas, as we have mentioned, are immediately transferable and cannot be seized nor fenced-off once expressed and in this way are quite resistant to the possibility of holding effective property rights. This had been a simple matter only because the cases in which property rights were extended over ideas whose use required significant capital investment (presses, prototypes). Thus, the only parties capable of infringement of a meaningful kind were those who engaged in large-scale production, and were thus few in number, and conspicuous in both manufacture and distribution. With the cheapening and subsequent increasing availability of means of production the number of parties capable of infringement grew explosively, now virtually pervading the public sphere. Small-scale infringement became practical, and the line between significant infringement and insignificant "fair use" has become practically meaningless, for sufficiently widespread "fair use" when given access to the means of production becomes, in effect, a highly distributed large-scale system of production, as is the case in peer-to-peer networks such as Gnutella or KaZaA, or even merely in the collective effect of pervasive and commonplace exchange of digital products in person.[5]

Without centralized high-profile producers, and without the need of a centralized large-scale distribution system - for the exchange of non-commodified or de-commodified wares requires neither that they be advertised nor that they be made available for sale - effective monitoring of infringement becomes impracticable. There is no longer the possibility of identifying the single or small number of parties guilty of infringement; instead, there is a huge number of parties which are each responsible for an inconsequential degree of infringement, but which taken together nevertheless threaten the viability of corporations trading in such goods.

As discussed in the previous section, with the development of sufficiently advanced digital technologies the means of production have become publicly available, spawning a spontaneous communist economy that seems able to motivate socially necessary labor within this sphere of production without dependence upon capitalist commodification of goods. While this economy does trade in de-commodified wares - that is, wares initially produced from a profit motive, but redistributed, as warez, without a profit motive - the production of non-commodified wares in open-source communities continues to expand, both by means of the creation of goods for use-value and in the move from a commodity-market model of software production into a service-economy model of production.

These communist and service-based economies, furthermore, are in competition with the holdovers from these industries' capitalist past. Thus, we have a rather odd form of class warfare taking place: setting the predominantly middle-class computer-savvy masses, not against the capitalist or upper class, but against large national and multinational corporations themselves. The digital proletariat seeks to seize the remaining means of digital production not yet in their hands and to use these means to produce freely made goods to serve as a replacement for those produced by industrial capitalists. The capitalist holdovers seek to wrest productive power from the public and generally to ensure that as little as possible is available for free, but that as much as possible must be obtained through the marketplace.

Unable to act effectively against infringement, capitalist holdovers in revolutionary industries can hope to control the flood only through fear and violence. The MPAA and RIAA have taken legal action under the DMCA against academic researchers,[6] persons running personal web pages,[7] and private citizens. [8] Additionally, they have threatened to hold corporations accountable for the non-business related actions of their employees, [9] to hold employees accountable for the actions of their employers,[10] to hold commercial ISPs accountable for the actions of their customers, to hold universities accountable for the actions of faculty and students, and to hold parents accountable for the actions of their children.[11] They have also begun to pressure colleges and universities to monitor students on behalf of the media industries,[12] and to themselves prevent and punish copyright infringement on campus.[13] The MPAA senior vice president of worldwide anti-piracy, Ken Jacobson, accounted for these actions by explaining that "what we're trying to do is educate the population about what is appropriate, both from an ethical standpoint and from a legal standpoint" (Bowman 2001).

\section{Modern-Primitive Accumulation}

Even if the public interest were best served by preserving intellectual property rights in these cases, the public interest is certainly not served by such widespread and punitive "education" about "what is appropriate." These actions are not well described as education, but are much better characterized as a process of deliberate and systematic crippling of the productive powers of the public. This is nothing but a return to primitive accumulation as a desperate attempt to prop up a system that the movement of capital no longer reinforces. 
Marx describes primitive accumulation as the metaphorical original sin of capitalism; it is the nonmarket-based seizure of the means of production that forced labourers to sell their labour-power on the market rather than acting as producers themselves. That was necessary in order to put the capitalist system in place, after which time it is able to continue to run as a self-supporting system. As Marx explains,

The capitalist system presupposes the complete separation of the labourers from all property in the means by which they can realise their labour. As soon as capitalist production is once on its own legs, it not only maintains this separation, but reproduces it on a continually extending scale. The process, therefore, that clears the way for the capitalist system, can be none other than the process which takes away from the labourer the possession of his means of production... The so-called primitive accumulation, therefore, is nothing else than the historical process of divorcing the producer from the means of production. (Marx 1996: 705-6)

The capitalist holdovers in revolutionary industries must return to something like primitive accumulation. The means of production having come back into the hands of laborers though the process already described, capitalism has had its legs knocked out from under it by industrial production itself, this being, indeed, the reason why such industries can properly be called themselves revolutionary. In order to re-create this original sin, necessary for capitalist production to be a self-supporting system, those who seek to commodify intellectual products must separate laborers from their newly gained productive powers.

This, however, cannot in this case be accomplished by straightforward primitive accumulation, for the capitalist holdovers seek to sell intellectual products, which by their very nature, as we have already discussed, contain within them the means of their own reproduction. The solution sought is then the next best thing: to attempt to ensure that the productive employment of the means of production that can no longer be kept from laborers is as limited as possible, and that the products of this productive employment cannot serve the same functions as the commodified products of corporate manufacturing, thus maintaining an artificial dependency upon capitalist production of intellectual goods. This is achieved by means of what Michael Perelman calls advanced accumulation (1998:78; 2002:45), wherein the public is forced to pay for the privatization of public goods, and by means of a kind of systematic colonization of information itself, wherein an arbitrary and exclusionary system of laws ensures that only large corporations are allowed to fully utilize the means of production commonly available to most members of society.

Even these methods, however, will not make capitalist production of intellectual products again possible, for where industry has itself become revolutionary, it seems that a capitalist system becomes impossible. As the term was defined at the outset, a revolutionary industry is an industry that, through a radical cheapening of machinery, has made the means of production available to the laborer, and which has a vanishing small marginal cost in the production of its wares. Under these conditions, communist production has flourished and is currently in open competition with capitalist holdovers within the industry. The force of capital has shifted to support communist models of production, and capitalism only remains possible through legislative measures. The only recourse which the capitalist holdovers have available - other than allowing progress to occur peacefully - is to return to a variety of feudalism,[14] where laborers have access to the means of production, but must hand over all their work to the lords of the information industries, and must obtain all their digital goods, not from one another in a free exchange, but always and only through the mediation of corporate masters, who can thus set arbitrary and exploitative prices.

\section{| Three Ways of Being-Against Technology}

Cultural industrialists oppose the change implied by and contained within the form of digital technologies in three primary ways: (1) advanced accumulation, (2) systematic colonization, and (3) the attempt to bring about informational feudalism. Michael Perelman defines advanced accumulation in contrast to primitive accumulation, stating that

Rather than directly expropriating physical means of production, advanced accumulation is more indirect. It entails the marshalling of public resources to concentrate informational powers in the hands of great corporations or elite individuals. The public resources might be information proper or the means of conveying information, such as the communications spectrum. (Perelman 1998: 78)

Within the realm of patent law - his primary concern - Perelman gives a striking and very clear example of advanced 
accumulation soon after introducing the term.

With regard to pharmaceutical companies, he points out that they patent information obtained through university research, then sell a product based on this research, which, in the case of a successful product, he elsewhere estimates to generate about a million dollars in sales per day (Perelman 2002:195). Then, "When challenged [regarding pricing], the corporation will inevitably respond by claiming the need to recoup the expenses of its research, even though public research frequently forms the foundation for much vaunted intellectual property rights," (1998:80) clearly an ingenious claim when we consider for example, as he points out elsewhere, that "in 1992, the industry spent $\$ 1$ billion more on promotion of its drugs than on research and development" (2002:131).

He continues,

In a rather spectacular case, federally funded research was used to map the genetic structure of human beings. Private companies were then permitted to patent these genes. Those that control this valuable information then have the gall to call upon the full powers of the state to protect their intellectual property rights to human genetic material. (1998:80)

The case is similar with regard to copyright. Copyrighted material is protected at public expense, the cost of which, now that the means of production are publicly available, is already great and will be increasingly greater. Copyright laws use the time and energy of our elected representatives, and the enforcement of these laws clogs our courts and are conducted in large part at government expense, both domestic [15] and foreign. [16]

The "copyright bargain" is, furthermore, no longer a bargain at all, but is rather a seizure, for not only does the public pay to provide and protect the artificial monopolies of intellectual property capitalist industrialists, but the public also pays for these industrialists to bring about legislation and prosecution which prevents the public from free and fair use of the materials thus provided. This process at its base is the transformation of the public domain into capital, both through the use of public funding for private interests and through the privatization of the commons which was supposed to have been given back to the public as the public's end of the bargain. Advanced accumulation takes from us economic and personal independence and gives us Independence Day in its place.

\section{Re-Colonization}

Furthermore, there is a process of systematic colonization of information itself. In the systematic colonization of information - a process that overlaps to a significant extent with advanced accumulation in terms of both methods and goals - individuals are kept from the full and free use of the means of production already in their hands. In order to outline how this is done in the realm of information, we will begin by looking at the idea of systematic colonization in a conventional sense.

Marx, in his discussion of E.G. Wakefield's England and America, states that

We have seen that the expropriation of the mass of the people from the soil forms the basis of the capitalist mode of production. The essence of a free colony, on the contrary, consists in this - that the bulk of the soil is still public property, and every settler on it therefore can turn part of it into his private property and individual means of production, without hindering the later settlers in the same operation. (Marx 1996:755)

This presents a problem for the capitalist, for workers no longer divorced from the means of production cannot be pressed into labor. But Wakefield has a solution:

How, then, to heal the anti-capitalistic cancer of the colonies? ... Let the Government put upon the virgin soil an artificial price, independent of the law of supply and demand, a price that compels the immigrant to work a long time for wages before he can earn enough money to buy land, and turn himself into an independent peasant... This is the great secret of 'systematic colonization.' (Marx 1996:758-9)

But as Marx points out, "this 'sufficient price for the land' is nothing but a euphemistic circumlocution for the ransom which the laborer pays to the capitalist for leave to retire from the wage-labor market to the land" (1996: 759).

Industries based on or around computers, especially the software industry, are in this way akin to empires. They must struggle in order to ensure that colonists who find themselves surrounded by free and available means of production do not use these means for their own subsistence and independence, but rather to support the motherland. 
The digital consumer is surrounded by rich and arable land. Software may be mined for ore, out of which new competing products may be made. Music may serve as not merely a product to be consumed, but seeds may be saved which can be cultivated into new and attractive varietals. The very look and feel of objects of our digital life, whether .html, .mp3, .mpg, or .exe, may inspire new creations.

In order to keep the production of digital objects from obtaining independence from commodification and from the capitalist motherland, corporate peddlers of intellectual property must ensure that colonists in digital lands are largely and for the most part unable to use the seemingly inexhaustible riches surrounding them to become independent producers - excepting if they should obtain sufficient capital to buy their way in. What is the price in this case? It is not a set amount, but the minimum is likely the amount required to acquit oneself of a spurious charge from a corporation employing a legal team. The maximum is 150,000 USD per infringing work, plus actual damages and lost profit projections.

Since the minimum price is unacceptably high for private individuals as well as small businesses, the safest bet is to simply pay the fees, even on spurious copyright and patent claims. The other option - and the one followed by top tech companies - is to amass a portfolio of intellectual property claims (spurious or not) that can be used to file counter-suits, forcing reasonable licensing agreements.[17]

Thus, the systematic colonization of information is more insidious than the conventional variety, for the price it sets for becoming a producer is so high as to prevent anybody from paying it who has not already become part of the analogical motherland, (i.e., who is not already engaged in capitalistic production of intellectual property and the processes of advanced accumulation) systematic colonization, and information feudalization which are required to make capitalistic production possible after industry has itself become revolutionary. However, systematic colonization of information can be avoided in a way that the conventional variety cannot, for it is not possible to produce land out of whole cloth, so to speak, but it is yet possible to produce digital objects without being subject to the claims of intellectual property.

The systematic colonization of information is being accomplished through (a) closed-sourcing, (b) governmentally guaranteed encryption, (c) licensing, and (d) the assumption of copyright. Through these means the digital colonist, while she cannot be separated from her land, is kept as much as possible from mining it, from trading or selling it, and from sustainably farming it.[18]

(a) Through closed-sourcing we colonists are prevented from improving upon that which we have purchased,[19] we are kept from a means of learning from the achievements and failures of others, and we are denied a valuable educational tool that would otherwise aid us in learning the tools of commerce. Closed-sourcing prevents us from free use of information that we have obtained in the marketplace; information that in some cases has been taken from the public domain.[20]

(b) Through encryption we colonists are denied access to information which we have legally obtained, thus making free use of proprietary and some non-proprietary information not only illegal, as it is under closed-sourcing, but actually impossible. Encryption of commodities, however, can always be circumvented, as I already noted above, for we can always tap into the data flow at the point of display or use. In order to further prevent us from use of these materials, encryption has been granted a legal status (Cf. DMCA anti-circumvention provision, U.S.C Sec. 1201(a)) that criminalizes access to encrypted information, thereby legally denying us not only creative use of but also mere access to information in our possession, such that we do not have the opportunity to do wrong, for under this legal protection of encryption, we may be cut off from even the intended use of products purchased if this use requires circumvention (as used to be the case for Linux users who wished to view a DVD - no CSS-licensed DVD software was available until as late as 2001 (Linux Online 2001), leading to the famous Jon Lech Johansen DeCSS case (Stecklow 2005) - and as is arguably the case now with iTunes-purchased DRM restricted content). Again, the trend in these cases of overprotection is to criminalize fair use rather than risk an erosion of corporate control of consumer activities, thereby removing from the public not only free use of purchased proprietary information, but also in some cases even public domain, copyright free, and non-proprietary information.

(c) Through licensing we colonists are prevented from saving seeds from our harvest for replanting, both literally[21] and figuratively. We can be prevented from use of our legally purchased product to make further copies, we can be prevented from lending our copy to friends and relatives, and we can be prevented accessing our copy from more than one location. [22] Through licensing we are stripped of ownership of digital objects, and, placed in the legal status of renter, subject to all manner of abuses and unfair contractual requirements.[23]

(d) Finally, through the assumption of copyright - that material is assumed to be copyrighted over its maximum term without notice to or registration with any centralized database - we colonists are prevented from the use of vast amounts of material that lies entirely fallow; [24] unoccupied and unused resources which the empire would rather fall to decay than be used by independent producers.[25] As Lessig asks rhetorically,

"But can't you just restore the film, distribute it, and then pay the copyright owner when she shows up?" Sure, if you want 
to commit a felony. And even if you're not worried about committing a felony, when she does show up, she'll have the right to sue you for all the profits you have made. So, if you're successful, you can be fairly confident you'll be getting a call from someone's lawyer. And if you're not successful, you won't make enough to cover the costs of your own lawyer. Either way, you have to talk to a lawyer. And as is too often the case, saying you have to talk to a lawyer is the same as saying you won't make any money. (2004:224)

Of course, if one does not even attempt to make a profit, one may still be committing a felony, [26] and is still liable for damages to the copyright holder, and one will likely be, in the end, just in a worse situation if the lawyers should arrive.

Through these four primary avenues, and in other ways less important and too numerous to discuss in detail, the capitalist holdovers have put legal barriers in the way of the use of the digital bounty all around us. The effect is the systematic colonization of information itself: only corporations and economically elite individuals are able to pay the prices required in order to freely put information to use. Only they can afford the expense of a lawsuit, and we mere colonists cannot fight even a spurious and unjust claim of infringement without devastating loss of property and livelihood. Only they can afford to pay the absurd and exclusionary fees attached to legal use of materials, fees that ensure that we colonists cannot ourselves become producers.[27] Furthermore, only they can pay the legislative equivalent of the poll tax: the immense amount of money that must be spent in most cases in order to get legislation on the table, and unless there is first a public uprising, we colonists would certainly be unable to marshal the resources to counterbalance the capital investments of intellectual property corporations in both lobbying and campaign contributions, if we should wish to pass legislation limiting the artificial monopolies of the intellectual property empire.

\section{Informational Feudalism}

As we have already noted, systematic colonization of information is in a way more insidious than systematic colonization of a conventional sort, for it sets the price of free use too high for common laborers. It must do this, for its industry has become revolutionary, and any common laborer can now produce goods on an industrial level; goods which can most certainly rival those of corporate capitalistic manufacture in terms both of quality and quantity, and most assuredly in terms of price. The overall end goal of this variety of systematic colonization is not then to ensure that an orderly and reasonable capitalist economy is created, for fair capitalist competition already brought about the spontaneous communist society that this systematic colonization is intended to disrupt. The overall end goal is instead to bring about a kind of feudalism, for it must to the greatest extent possible transform laborers into mere serfs, for in revolutionary industries a creative and industrious laborer can compete with any magnate.

As Lessig explains his version of this parallel,

Under feudalism, not only was property held by a relatively small number of individuals and entities. And not only were the rights that ran with that property powerful and extensive. But the feudal system had a strong interest in assuring that property holders within that system not weaken feudalism by liberating people or property within their control to the free market. Feudalism depended upon maximum control. (2004: 267)

Lessig is concerned here with the hostility not merely towards those who object to the strong property rights granted over intellectual property but also towards intellectual property rights holders who wish to release their own work into the public domain. This latter form of hostility is exemplified by U.S. Patent and Trademark Office acting director of international relations Lois Boland, who stated that "open-source software runs counter to the mission of WIPO, which is to promote intellectual-property rights," and that "to hold a meeting which has as its purpose to disclaim or waive such rights seems to us to be contrary to the goals of WIPO.” (Lessig 2004: 265)[28]. This hostility cannot be explained by a commitment to property rights, for as Lessig points out,

even if one believed that the purpose of WIPO was to maximize intellectual property rights, in our tradition, intellectual property rights are held by individuals and corporations. They get to decide what to do with those rights because, again, they are their rights. If they want to "waive" or "disclaim" their rights, that is, within our tradition, totally appropriate. (2004:266)

This hostility towards any broadening of the public domain does indeed go beyond advanced accumulation 
and systematic colonization, but does not itself constitute informational feudalism. In addition we need to consider contemporary analogs of three other aspects of traditional feudalism: (1) the way in which labor power is the property of the land rather than of the laborer (as is the case in capitalism) or of other humans (as is the case in slavery), (2) the way in which guild structures ensure that laborers are unable to wield their productive power as individuals, and (3) the overall structure within this bipartite system which amounts to an unchanging caste system determining the ability to freely use the means of production which are, however, in the possession of all.

In the feudal economy, land is given over to nobles who extract a tribute from those who work and live upon the land. Thus, "Like tribal and communal ownership, it is based again on a community; but the directly producing class standing over against it is not, as in the case of the ancient community, the slaves, but the enserfed small peasantry" (Marx 1932). However, here the means of production assert a kind of dominance over the community for "The serf is the adjunct of the land. Likewise, the lord of an entailed estate, the first-born son, belongs to the land. It inherits him" (Marx 1959). Further,

This feudal system of land ownership had its counterpart in the towns in the shape of corporative property, the feudal organization of trades. ... The gradually accumulated small capital of individual craftsmen and their stable numbers, as against the growing population, evolved the relation of journeyman and apprentice, which brought into being in the towns a hierarchy similar to that in the country. (Marx 1932)

In the informational feudalism which the capitalist holdover seeks to bring about there is no clear analog to this bipartite town/country division, but our position as laborers in informational economies takes on aspects of both serfdom and guild membership, and our position as consumers takes on aspects of those freemen who are neither serfs nor guilded, with the exception, of course, that we have means of subsistence not altogether dependent upon informational economies.

In informational feudalism, we would be born serfs. Born onto lands already owned by others, we would be able to use our productive force only insofar as we pay tribute to the noble landowners. We could write only insofar as we pay for Microsoft Word, and insofar as we pay for the updates required by the updates of our operating systems, which are in turn required for our continued compatibility with those who have already updated their software. Furthermore, our consumption would be limited to those provided by these lords; we could listen to music and watch movies only by paying tribute to labels and studios. We would be born and live out our lives upon cultural soil already and always ever owned by the few and the powerful.

In order to profit from our productive powers to create goods, we would have to join guilds. To publish we would have to prove our worth to publishing houses and agree to their terms. To record and release music, we would have to join a label, for only they would be able to convince (i.e. pay in cash or kind) the radio conglomerates to play our music. To film and release video, we would have to sell ourselves over to the interests of studios or networks, for only they can withstand a charge of infringement. To create software or games, we would have to become a part of a large software company, for only they can stockpile the patents needed in order to negotiate release of applications. In each case, the guild keeps not only the greater part of the profits, but usually also keeps the majority of ownership rights over our products.

Others are then born into our products, which we cannot allow them free use of, for our guilds and lords retain ownership of them. Thus, the world which the copyright warriors wish to bring about is not only feudalistic in that it depends upon suppression of making informational goods freely available, but also in that it would establish an unchanging caste system in which only the few could ever freely use resources in the possession of all, and in which the many can only ever use the means in their possession by virtue of their fealty to the few, thereby reducing us to serfs belonging to the very lands we work.

As Lessig says, "the question now is whether [information society] will be free or feudal," just as Roger Garaudy wrote in 1969, when he asked whether digital technologies will "bring about renewed alienation in a technocratic form of totalitarianism, or an unprecedented liberation of the creative potential in man, in each and every human being" (1970:11). This is a question that we have the responsibility and privilege to answer. A complication which we must consider, in framing this question, is that however rhetorically effective and descriptively compelling they may or may not be as metaphors and analogies, ultimately 'feudalism' and 'serfdom' insufficient descriptions of our emerging relation to productive forces.

G.A. Cohen describes "ownership positions of immediate producers" as follows: the serf owns some of his labor power and some of the means of production; the proletarian owns all of his labor power and none of the means of production; an independent producer owns all of both; and a slave owns none of either (1978:65). Cohen 
then goes on to describe the different combinations which do not appear in the standard set, the first of which - (5): he who owns none of his labour power but all of the means of production - Cohen claims "depicts an incoherent set of rights. For if $\mathrm{X}$ is the sole owner of all the means of production he uses . . he is entitled to use them without the direction or interference of another person. Yet (5) also states that $\mathrm{X}$ has no authority whatsoever over the disposition of his own labor power" (1978:66). Surely Cohen is right in claiming that this situation is incoherent, and yet in some important aspects this seems to be the regulative ideal for the consumer under informational feudalism. We see this more clearly in his ongoing discussion:

(5) is the mirror image of the proletarian ... The proletarian may do anything he wishes with his labour power, short of violating the general laws of society, and nothing may be done with it without his contractual consent. He may not, of course, work with whatever means of production he chooses, but this follows from the exclusion of illegal behaviour in general. For parity, the person described in (5) should, in virtue of his supposed ownership of means of production, be able to do whatever he wishes with them within the law, yet this is excluded by his being forbidden to work with them as he wills, which is not a general law, but a legal feature of his particular situation. (1978:66)

Today, of course, there is a law which forbids from doing "whatever we wish" with the intellectual goods we purchase, and yet it is still the case that we own copies of $\mathrm{mp} 3 \mathrm{~s}$, DVDs and applications. And, further, with digital objects it is impossible for us to own the digital consumer object without also always already owning the means of production of it. For these reasons, I hold that it is more appropriate to say of our digital serfdom that, with regard only to our lives in relation to intellectual goods, that intellectual property maximalism moves us towards a situation wherein we could be appropriately said to own all the means of production, and yet not own our labourpower with relation to them; a kind of regional approximation of (5) above. We might describe this situation as the ideal consumer: the ideal consumer has access to the means of production, and yet is unable to do anything with them, and therefore must always purchase in order to consume. Again, a chief example here is the farmer who has every opportunity, but not the legal right, to save seed from harvest to replant; we are prevented from becoming independent producers, not because we have no access to, or cannot afford the means of production, but simply because we are legally prevented from using it, either directly through intellectual property rights, or indirectly through the fear of litigation and collusion of industrial producers. [29]

Thus, abandoned by capital, capitalists have used laws intended to bind their hands in order to prohibit productive forces from further development. In doing so, they have appropriated the functionaries of the governments, both domestic and foreign, in order to keep wage-laborers from the productive use of the means of production now within their hands. Through advanced accumulation, they rob the commons at public expense. Through systematic colonization, they prevent our use of that which has been taken from the commons. Together, these work to bring about informational feudalism, in which our lives are lived on their property, and we have no choice but to consume what they provide at the prices they set, to produce only by their fiat, and to sign our own work over to them if this work is ever to reach the public.

This program has not yet been completed, and even if it were completed, it would still only be further grist in the mill of history, which, if we sign on to some version of technological determinism, would progress inevitably away both from capitalism and from its regressive neofeudal stopgap as well, towards a future of communal, bazaar-model intellectual production. However, regardless of our views on determinism, this future is already with us in at least an inchoate form - the inchoate communistic economy, spontaneously arisen from the public availability of the means of production, which is embodied within the open source movement and $\mathrm{p} 2 \mathrm{p}$ networks. We have yet an opportunity to bring the future sooner rather than later, and with less upheaval now than in the future when feudalism may have gained sway despite the resistance of the means of production themselves. We must resist; we must riot in the online streets, and we must work our digital plowshares into swords. We must rip, we must mix, and we must burn.

\section{Endnotes}

1. Despite this, I will nevertheless have to refer to this class in the following. In order to avoid involvement in debate about its proper name or characterization, I will use the dummy-term "digital proletariat," or, later, "we colonists."

2. Although G.A. Cohen is right to assert that, for Marx, the breakdown of capitalism itself was insufficient to 
establish socialism or communism unless a sufficient level of technological development had been first attained. As Cohen summarizes:

Believing that a developed technology was an essential precondition of socialist success, Marx would be pessimistic about attempts to 'build socialism' from a baseline of comparative scarcity and industrial immaturity. But since he thought high technology was not only necessary but also sufficient for socialism, and that capitalism would certainly generate that technology, his final position was optimistic. (Cohen 1978:206)

Please do note, however, that this claim that "high technology" is "sufficient" for socialism is still not the claim that I will make here: that digital information technology is not merely sufficient but actually effective - actively revolutionary in important ways - in bringing about communistic production within its own, admittedly limited sphere.

3. It has been said that for this reason, any attempt to protect digital information from copying must necessarily fail. The argument is that the digital information must be decrypted at some point, for it is used in a non-encrypted form. No matter how complex the system of protection, it will always be possible to tap into the data stream at the point of display or use. A nice example of the way in which wares can exploit this point of contact is presented by programs such as ourTunes (http://ourtunes.sourceforge.net/) and Blue Coconut (http://husk.org/apps/blue_coconut/), which connect at the user-end to iTunes' music sharing function, allowing a user to download a shared file through iTunes, despite the fact that iTunes itself, which provides the streaming of the music file, is specifically designed to prevent such downloading.

A particularly dramatic example is provided by MyTunes, a program which performed this same circumventive function. As John Borland reported,

as some predicted, the popular software has all but vanished from the Net, and its programmer's sites have gone dark. But this time, it's not the doing of an angry record industry or a conflict-averse Apple. Trinity College sophomore Bill Zeller, who wrote the program in less than two weeks of off-time coding last year, says he simply lost the source code in a catastrophic computer crash.

"I was about to release the second version, when I lost everything," Zeller said. "I may put it back online, but there won't be any updates. I don't want to rewrite it." (Borland 2004)

The very fact that a college student can circumvent corporation-produced DRM systems in his spare time, with a level of commitment as minimal as we see in his comments here, supports the basic intuition that the project of preventing access through the technical means of closed-sourcing, encryption, and DRM is essentially doomed.
4. For example, Courtney Love argues very effectively that even a band with a million-dollar advance, a $\% 20$ royalty rate, which sells a million copies of their album, nevertheless "might as well be working at a 7-Eleven." She introduces this example by asking rhetorically, "What is piracy? Piracy is the act of stealing an artist's work without any intention of paying for it. I'm not talking about Napster-type software. I'm talking about major label recording contracts." (2000) Love then goes on to explain how musicians have been legally denied ownership, for perpetuity, of the copyright for their music via the Satellite Home Viewing Act of 1999, wherein such creative works were reclassified as 'works for hire,' a designation which does not otherwise cover creative or original works.

5. The practical similarity between the online exchange and the personal exchange of digital files is recognized in references to the "sneakernet." The term originated with the observation that where it is impossible or imprudent to exchange such materials on the internet, one can always put on one's sneakers and exchange the files in person; that is, over the "sneakernet."

6. Dr. Edward Felten, after receiving a threatening letter, was moved to decline to present an academic paper that used research garnered from a public challenge funded by the Secure Digital Music Initiative. As he explained,

On behalf of the authors of the paper "Reading Between the Lines: Lessons from the SDMI Challenge," I am disappointed to tell you that we will not be presenting our paper today. Our paper was submitted via the normal academic peer-review process. The reviewers, who were chosen for their scientific reputations and credentials, enthusiastically recommended the paper for publication, due to their judgment of the paper's scientific merit. Nevertheless, the Recording Industry Association of America, the SDMI Foundation, and the Verance Corporation threatened to bring a lawsuit if we proceeded with our presentation or the publication of our paper. Threats were made against the authors, against the conference organizers, and against their respective employers. Litigation is costly, time-consuming, and uncertain, regardless of the merits of the other side's case. Ultimately we, the authors, reached a collective decision not to expose ourselves, our employers, and the conference organizers to litigation at this time. (Felten 2001)

Full text of Dr. Felten's letter, along with the threatening letter from The Secure Digital Music Initiative (SDMI), a music industry organization, is available at http:// cryptome.org/sdmi-attack.htm. Full text of the paper the authors chose not to present is available at that site, or at http://www.usenix.org/publications/library/ proceedings/sec01/craver.pdf

7. For example, Dave Touretzky's home page, available at http://www-2.cs.cmu.edu/ dst/. The letter reads, in part, 
We have received information that you are unlawfully offering product at the above referenced web site. We have notified your ISP of the unlawful nature of this web site and have asked for its immediate removal. Our letter to your ISP is set forth below for your reference. (Motion Picture Association of America 2001)

The appended letter to the ISP, in this case, CarnegieMellon University, reads in part

The district court's ruling makes clear that by providing DeCSS, the above referenced Internet site violates the DMCA. This conduct may also violate the laws of other countries, international law, and/or treaty obligations.

We therefore demand that you take appropriate steps to cause the immediate removal of DeCSS from the above identified Internet site, along with such other actions as may be necessary or appropriate to suspend this illegal activity. Failure to comply with this measure will subject you to liability as described above.

We also request that you:

- maintain and take whatever steps are necessary to prevent the destruction of all records, including electronic records, in your possession or control related to this Internet site, account holder or subscriber, and

- provide appropriate notice to the subscriber or account holder responsible for the presence of DeCSS on your system or network, advising him/ her of the contents of this notice and directing that person to contact the undersigned immediately at the email address provided above.

- By copy of this letter, the owner of the above referenced Internet site and/or email account is hereby directed to cease and desist from the conduct complained of herein. (Motion Picture Association of America 2001)

A similar letter was sent to John Young, with the additional demands that he

- advise us of the name and physical address of the person operating this site; and

- maintain, and take whatever steps are necessary to prevent the destruction of, all records, including electronic records, in your possession or control respecting this URL, account holder or subscriber. (Motion Picture Association of America 2000)

8. The dispute is not about whether the RIAA will be able to force Verizon to reveal the identity of a suspected copyright infringer, but about what legal mechanism copyright holders may use. The RIAA would prefer to rely on the DMCA's turbocharged procedures because they are cheaper and faster than filing a "John Doe" lawsuit to unmask a peer-to-peer user.

This case represents the entertainment industry's latest legal assault on peer-to-peer piracy. If its invocation of the DMCA is upheld on appeal, music industry investigators or other copyright holders would have the power to identify hundreds or thousands of music pirates at a time without filing a lawsuit first. (McCullagh 2003)

It is worth noting that such peer-to-peer users may in fact own the material being downloaded, e.g. on $\mathrm{CD}$, and may therefore be engaging in "space-shifting;" a practice which has been recognized as fair use of legally obtained material. However, under the DMCA, this kind of legal action may be taken against what may thus be only apparent infringement.

9. "The Recording Industry Association of America (RIAA), the Motion Picture Association of America (MPAA) and songwriters' associations have drafted a letter expected to be sent Friday to the Fortune 1000 companies, cautioning executives that employees' song- or movie-swapping could put them at legal risk." (Borland 2002a)

10. Adobe Systems filed a complaint with the Department of Justice against ElcomSoft Co. Ltd., on grounds that they were selling 'a circumvention device' as defined under DMCA \$1201(a). Dmitry Sklyarov, a citizen of Russia, and Ph.D. student, and ElcomSoft employee who had been in the United States at the time presenting at an academic conference sponsored in part by Adobe Systems, was arrested in July 17, 2001, and held until December of that year, when he was allowed to return home. A year later ElcomSoft was cleared of all four charges of producing a circumvention device, as well as the charge of conspiracy. (Bowman 2002a)

11.

AT 6:30 ON A WARM MORNING IN JULY 1995 NEAR Salt Lake City, Miki Casalino was suddenly awakened by the ringing of her doorbell. When she opened the door, a troop of United States marshals and Novell employees flashed a court order and announced, "We've come to seize your son's computer." Although Casalino had no idea her 18-year-old son was illegally pirating Novell's and other programs on his bulletin board service, she was guilty in the eyes of the law. The marshals raided the house, impounded the computer equipment, and left. Another software pirate shut down. (Rothken 1998)

12.

In a letter sent to more than 2,000 university presidents, the Recording Industry Association of America (RIAA), the Motion Picture Association of America (MPAA) and other copyright owner trade groups told university officials that large numbers of students were using college resources to violate federal law. 
"We are concerned that an increasing and significant number of students are using university networks to engage in online piracy of copyrighted creative works," the trade groups wrote in a letter sent to universities this week...

The letter, which the trade groups asked college presidents to send to university legal, financial and technological executives, stops short of threatening any kind of legal action. (Borland 2002b)

13. For example, Cornell University informed its students in 2002 that students may be subject to disciplinary actions within the school even if they comply with a request to remove copyrighted files. Tracy Mitrano, the DMCA Agent for Cornell University, warned that

without your knowing it explicitly, by downloading [certain file-sharing programs] and the files, your computer is programmed to share it back out into the international Internet community. You are then therefore liable to be in violation of the DMCA, even if all you did was download a single song. Each criminal offense carries with it a minimum fine of $\$ 30,000$ and a potential jail sentence.

Ms. Mitrano also noted: if you don't like or disagree with the law, learn more about and take a stand on it in the arena of national politics. With implications for free speech and academic inquiry, it might just become the political issue of your generation." (Miltrano 2002)

Another interesting example is the U.S. Naval Academy, which took possession of about 100 students' computers due to suspicion of copyright infringement:

Each student gets a computer when they enter the academy. Illegal possession of copyrighted material could carry punishment including court-martial or a loss of leave, according to academy policy. The seizure comes just a few weeks after movie and music industry trade groups sent a letter to more than 2,000 university and college presidents across the country, including officials at the Naval Academy, requesting help in cracking down on unauthorized file swapping. (Bowman 2002b)

14. I am not alone in using this characterization, see, for example, Information Feudalism (Drahos and Braithwaite 2003). Lawrence Lessig also characterizes the goal of at least some of the "copyright warriors" as turning the information society into a feudal society, noting that already "the trend is toward the feudal." (Lessig 2004:267)

I should also say something about why I do not reference Drahos and Braithwaite's book to a greater extent in my discussion of informational feudalism to follow. Drahos and Braithwaite do not make a particularly strong case that the emerging situation is best characterized as feudalism rather than some other kind of consolidation, nor, I should take care to note, do they attempt to, as this is not their project. Their idea of feudalism is exhausted for the most part by what I will discuss in terms of advanced accumulation and systematic colonization, as may be clear from a fairly characteristic passage:

By reproducing the times tables, growing their own seeds, using traditional medicines or selling indigenous art [citizens] may be trespassing on an intellectual property right that has been appropriated by a large company. ... This is what we mean by being a trespasser on your own heritage. ... This is what information feudalism means. When Monsanto contractually imposes obligations on farmers using the lever of its control over intellectual property in seeds, Monsanto does act like the feudal lord who allows serfs to till his land so long as they honor the obligations that are his due. (Drahos and Braithwaite 2003:201)

The idea of informational feudalism which I am trying to put forth is somewhat more robust and precise than theirs. This should not be in any way taken as a criticism of the book, which is well researched and argued. My intention in this comment is only to explain why I do not further reference the work in connection with the charge of feudalism, and to differentiate my use of feudalism from theirs.

15. Bob Kruger, Vice President of Enforcement for the Business Software Alliance (BSA), said "We don't like to call [an audit] a raid, but in reality that's what they are - raids." He goes on to describe these raids. As paraphrased;

Once the alliance has a judge's $\mathrm{OK}$, a team of auditors--usually BSA accountants with laptops-shows up at the business under suspicion, along with a few U.S. marshals. The auditors check what software is on each computer, then asks to see the company's licenses. For each software use for which the firm doesn't have papers, it's fined. While each violation carries with it a fine of up to $\$ 150,000$, Kruger says, the actual figure comes down to a dance between BSA lawyers and the offending party's chosen representatives. $\mathrm{He}$ assures me that the alliance's intent is to make its point via the company's bottom line: 'It's one awfully rude way for companies to realize it's a lot more expensive to violate copyright laws than to comply with them. (Jackson 2001)

16. There follow a sampling of examples of international governmental support of the Business Software Alliance, a trade group concerned with primarily U.S. interests, and with particular US software companies, Microsoft in particular.

\section{Australia}

A coordinated international crackdown saw premises across the country raided and computer equipment seized by the federal police last week, although no arrests have been made to date.

Many ZDNet readers have expressed anger at what they consider to be the police enforcing 
copyright law for big software businesses whose own "inherent weaknesses" in software design are the root cause of the problem. Software houses should "put up or shut up" one reader said and not be so keen to spend taxpayers' money.

"Personally think the police should keep themselves concerned with bigger cyber crime issues like child pornography or Denial of Service attacks. Not raiding peoples' homes and taking computer equipment just because some software or movie company might lose a bit of money. They need to get their priorities right," another ZDNet reader from Western Australia said.

Retired computer engineer Keith Styles from Melbourne agreed: "Let the police do their job of policing for the community and stop working for big business corporations. Copyright is a business problem not a police problem. Let the [corporations] do their own dirty work" (Lebihan 2001).

\section{Canada}

$[\mathrm{M}] \mathrm{y}$ workplace received a visit from the Software Gestapo. It's part of a campaign organized by a number of software developers (Microsoft, Adobe, Symantec and a number of others) to reduce software piracy in the workplace and schools. They call themselves CAAST, the Canadian Alliance Against Software Piracy. Although I am no thief, I understand that companies deserve to be paid for their work, but it begs two questions: A) Can companies do this? B) How long until they start searching my home?

A team of middle aged men in semi-formal attire, stereotypical tech guys, swept the building, checking every computer to make sure that we weren't using software that we hadn't properly remunerated the developer for. We knew they were coming, and made sure that our site licenses were in order. From what I know, their lengthy visit went without a hitch. The men were polite, nicely asking each employee if they could take a moment to do an inventory of their workstation. They ran a program that did a quick scan of all applications on the machine, and sent the data to a network server. What they did with the data after that, I'm not sure.

The situation begs another question: why did they give us advanced notice? Granted, we would be pretty annoyed if they showed up out of the blue, but for all they know, we could have unloaded any pirated apps the night before. Quite simply, they weren't there to catch us, they were there to scare us. To send a message, 'the days of pirated software are over. We're watching you.'

I, for one, was scared, despite my innocence. Here, I had men, sent by a company (or a coalition of companies, technically), enforcing the law. The government wouldn't do anything to enforce the laws, they have bigger things to care about, so the companies took the law into their own hands, and it's being allowed to happen. What rights do companies have to become vigilantes (Agent000 2001)?

\section{Croatia}

Microsoft Corp. said it has stepped up its crackdown on software piracy in recent months and announced actions against 7,500 Internet listings for allegedly pirated products in 33 countries...

In Europe, the Middle East and Africa, the company said it has taken action in 2,274 instances of suspected piracy, sending notices to Web-site owners asking them to remove products listed for sale. It has filed four lawsuits and taken part in 56 raids with law-enforcement officials in that region; in Croatia alone, police in late March simultaneously raided the premises of 52 alleged pirates (Buckman 2000).

\section{England, Finland, Norway}

To hear the federal government and piracy experts describe it, DrinkOrDie, the network of software crackers that was the focus of worldwide antipiracy law enforcement action on Tuesday, is the al-Qaida of Internet software theft....

"They come from all walks of life. Many are successful white-collar business people by day, and DrinkOrDie members by night," [the U.S. Customs Service] said in a statement....

But when the news broke that the Customs Service, the Department of Justice and foreign authorities executed at least 100 search warrants in the United States, Australia, England, Finland and Norway on Tuesday in an attempt to "dismantle" DrinkOrDie, a lot of people were puzzled. According to the evidence available from several cracking sites, Internet newsgroups and members of the Warez or "software cracking" - community, DrinkOrDie was small potatoes in the world of software theft. ...

"Only peasants get caught," wrote MoRf, a cracker in Moscow, in an online chat room" (Manjoo 2001).

\section{Ghana, Nigeria, Cameroon}

Microsoft Corporation, a multi-national software company, last Thursday launched an anti-piracy campaign to clamp down on piracy within some Ghanaian companies.

The campaign, the company said, was a nationwide exercise that had already started in Nigeria and Cameroon....

[Mr Franck-Alex Thalmas, Microsoft Anti-Piracy 
Manager in charge of West and Central Africa] said companies would be asked to take inventories of their software pack and licenses to attest the legality of the software in usage regarding the law and license agreement.

"If we are satisfied about the information provided we would issue a certificate of compliance to give them the authorization to use the software," he said (Accra Mail 2001).

\section{Malaysia}

Following the promise to intensify efforts to crackdown on software piracy amongst endusers the enforcement division of the Ministry of Domestic Trade and Consumer Affairs yesterday raided the premises of a publishing company in Kuala Lumpur for suspicion of using pirated software in the course of conducting its business. ...

"There is just no excuse. Since the beginning of this month, the Ministry with the cooperation with the Business Software Alliance has advertised extensively in the newspapers and radio to remind senior managers and company directors of the consequences of ignoring the Ministry's warnings." [said Tuan Mohd. Shahar bin Osman, The State Director of Enforcement (Ministry of Domestic Trade and Consumer Affairs) for Wilayah Persekutuan.]

According to the Copyright Act 1987, if an organization is found guilty of copyright infringement, the company and its director/s may be liable to a fine of up to RM10,000 per infringing software and/or up to five years jail term.

Speaking on behalf of the Business Software Alliance, Mr. Chee Chun Woei, Vice-President of BSA Malaysia said, "Companies need to be aware that using pirated software does not simply mean using an illegal piece of software bought from the streets. Indiscriminate copying from an original CD-ROM is also an act of piracy if the license agreement does not allow it." ...

In complementing the enforcement program of the Ministry, the BSA operates a toll-free hotline number 1-800-887-800 for reports of the use of pirated or unlicensed software in organizations. The BSA provides a reward of up to RM20,000 for every piece of information that results in a successful enforcement action (Business Software Alliance 2001).

\section{Pakistan}

In the latest move, BSA, the alliance of world's leading software companies has got another three software pirates arrested in Karachi, in assistance with the police.
All the eleven personal computers (PCs) loaded with the counterfeit computer programmes and the 29 illegal compact disks (CDs) were seized from their possession as a proof of infringing the country's copyright laws, he said.

The businesses that can afford to use legal software must do so in their own and national interest, [Jawad Al Redha, Director, Business Software Alliance (BSA), Middle East] suggested and clarified when someone creates a new computer programme and his creation is possessed without paying due royalties then it amounts to stealing, "which is neither morally nor legally justified" (Contact Pakistan 2001).

\section{Singapore}

Seven raids were conducted in October, across the island's heartlands like Toa Payoh, Ang Mo Kio, Marine Parade and Bedok North. This is because activity at the traditional centre of pirated goods, Sim Lim Square, has largely been stamped out by police action. The raids turned up over 4,000 pieces of illegal Microsoft goods....

Microsoft corporate attorney Katharine Bostick said in a statement that the pirates wanted to exploit the worldwide marketing effort for Windows XP. "Not only are these pirates ripping off legitimate software retailers," she said, "they are exploiting the creativity, hard work and investment made by software developers and industry partners."...

The number of people apprehended in the raid was not given. However, those convicted of piracy can face up to seven years' imprisonment (Tsang 2001).

\section{South Africa}

[T] ]he SA [South Africa] Federation Against Copyright and Theft (SAFACT) has declared war on counterfeiting, saying it will be 'embarking on more raids which are expected to lead to convictions' during 2002. It will also be working more closely with other stakeholders, including software companies such as Microsoft.

Fred Potgieter, MD of SAFACT - an organization which represents distributors such as Ster Kinekor and $\mathrm{Nu}$ Metro - said his organization along with other business partners such as Microsoft has assisted the South African Police Services, customs and the Department of Trade \& Industry in 'an increasing number of raids and counterfeit product seizures.

During 2001 SAFACT conducted 680 inspections and led 133 raids. The organization seized 7584 VCs, 6714 DVDs, 5124 CD-ROMs, while a total of 38 cases were finalized...

Commenting further, SAFACT's Potgieter said 
his organization is also working more closely at a grassroots level to combat counterfeiting.

"'We began an initiative last year which is starting to bear fruit. The major flea markets indicated their willingness to work with SAFACT in combating piracy. This lead to us creating a Memorandum of Understanding between our industry and the flea markets which will see all products being authenticated before the exhibitor is allowed to sell. These are all major steps.

"Our other major objective - besides clamping down on flea markets - is to target roadside traders. This is one of the biggest problem areas when it comes to counterfeit sales," said Potgieter (Microsoft South Africa 2002).

\section{Sweden}

MindArk AB, the Swedish creators of the 3D virtual Universe "Project Entropia" was raided by 70 officials of the Swedish court, acting on behalf of Microsoft and three other software companies.

Microsoft has accused MindArk of infringement on their software rights, stating that MindArk is willingly and unlawfully using over 600 programs without license. The raid on the MindArk headquarters in Gothenburg is believed to be the largest operation ever conducted by a Swedish court....

Jan Welter Timkrans, the managing director of MindArk AB, said: "MindArk has duly procured licenses for all software used in its offices. I would even go so far as to say that MindArk is one of the companies with the most stringent policies regarding software licenses in use by its employees.

"One can expect that Microsoft and the other companies are keeping track of what and to whom their representatives are selling software. In some cases the registration process involves direct contact between our company and Microsoft or its colleagues. With this in mind, Microsoft must be assumed to know that what they have stated to the Swedish courts is not the full truth, therefore I must assume that Microsoft must have another agenda for their action against MindArk."

Jan Welter Timkrans suggests that Microsoft is trying to disrupt the launching of Project Entropia: "All through our development process we have kept track of which companies are visiting our site on the Internet and without comparison Microsoft has been one of the most frequent visitors."...

Microsoft of course owns Asheron's Call, which MindArk says is similar to Project Entropia (PC Game News 2002).

\section{Thailand}

Note the implied claim of the journalist; "being fuzzy about the concept of intellectual property rights" seems to be substantiated by a claim, on the part of Amorn, that the pricing structure is unfair and exploitative.

At Panthip Plaza, a shopping center specializing in computer gear, antipiracy raids are a seasonal affair. "The police come about twice a year, once in June or July and then before the new year," says Mr. Amorn, who owns eight software stores that sell mainly pirated compact discs. "We know because the police tell us. For the software pirates of Thailand, cat-and-mouse raids are just part of their business. Copyright infringement, say the pirates, is here to stay. The incentives for buyers and sellers are just too great.

"It now costs as little as 50 cents to produce a pirate CD," says an American analyst here. For $\$ 10$, computer buffs can pick up CDs bundled with thousands of dollars worth of illegally copied software. "You can buy Oracle's database system for $\$ 25$, whereas it would cost you around $\$ 20,000$ to buy the real thing," Amorn says. "Look at [Microsoft Corp. chairman] Bill Gates; he's the richest man in the world."

Dhiraphol Suwanprateep, a Thai lawyer working for the BSA in Bangkok, agrees. "There is a feeling among some people that the pirate software dealers are simply engaged in competitive business practices against companies who are charging too much for their product," he says.

"Outright corruption is a factor, too," says an American analyst, who asked not to be named. "There's a bidding war between private software companies and the pirates. They're both trying to buy the police's support."

The BSA maintains that prices and piracy shouldn't be linked. "If you have the money to buy a car, then you should have the money to pay for the gas to run it," points out Mr. Dhiraphol. "With computers, it's the same. If you buy a computer, you have to plan for the cost of software."

Mr. Tan of the BSA puts the issue in even starker terms. "Whether the economic situation is good or bad, people should realize that software piracy is illegal," he says.

Supporting that line, the US government has been dangling antipiracy incentives. In 1993, the US Trade Representative named Thailand as a "priority foreign country" and withdrew preferential trade privileges on 16 items.

That hard-line approach brought quick results. By 1995, Thailand had a new copyright law stipulating penalties of up to four years in prison and fines of $\$ 20,000$ for offenders....

At their most extreme fringe, software pirates hit 
back at critics with nationalist arguments. "I don't see why we in developing countries should pay the same amount as Americans for software," said a Thai journalist, echoing their argument at a recent BSA press conference in Bangkok.

Realists say piracy will remain a problem for many years. "We are concentrating on both education and enforcement," Tan says. "The emphasis is on making people understand the value of intellectual property. Right now, we're focusing on businesses, government, and universities."

Just in case that message doesn't get through, the BSA has set up a hotline in Bangkok and is handing out cash rewards of up to $\$ 6,000$ for information leading to the prosecution of pirates or companies using illegal software (Yvan Cohen 1997).

17. "Patents most benefit behemoths with huge patent portfolios. IBM, the No. 1 holder, has about 20,000 that generate more than $\$ 1$ billion a year in licensing fees. But even giants such as Intel bemoan a system they say forces them to use big chunks of research budgets to stockpile patents just to use for cross-licensing when other patent holders threaten them" (Davidson 2004).

18. In two senses, one figurative, and one literal. Figuratively in that updates of software and unnecessary backwards incompatibilities, both within versions of a single program and between bundled programs, force us to continual upgrades even when there is otherwise no increase in use-value for us from one version to the next. This economic dependency is an exact analog of the economic dependency brought about through Monsanto's efforts to minimize actual sustainable farming techniques, as discussed below (see note 21 ).

19. For example, consider the anonymously produced "Phantom Edit" of George Lucas' Star Wars: Episode 1 - The Phantom Menace. The reader will note that this is one of the seemingly few cases where the corporate response is reasonable and measured.

When asked about The Phantom Edit while backstage at the MTV Movie Awards Saturday night, George Lucas told Zap2it.com that he wasn't too worried about it.

"The Internet is a new medium, it's all about doing things like that," said Lucas, who added that it gives people a new creative outlet. "I haven't seen it. I would like to."

The general consensus of fans on the Internet seems to be that the new edit is an improvement on the original version....JM Dash, one of the site's most prolific message board contributors, is also one of the film's most ardent supporters. "The stuff that has been cut out is all about making it a stronger movie and not just some fan cutting out the crap he/ she didn't like," he said. "If that were true, it would have just had the Darth Maul sequence looped for two hours." He also said, "[In the Phantom
Edit] Anakin is a stronger character. His crappy whoops and oops and that stuff is gone. It makes the kid seem like someone who is strong with the force and worth going against the council for as opposite to the whiny little kid in the original cut."

Jeanne Cole, a spokesperson for Lucasfilm, told Zap2it.com that because no one at the company had seen a copy of the re-edited version, they couldn't officially comment about the changes. Cole did explain her company's policy regarding copyright infringement, though. "Lucasfilm aggressively pursues anyone involved with the unauthorized sale of our copyrighted materials," she said. But Cole also added that Lucasfilm recognizes the fan following the Star Wars franchise has generated and said the company generally doesn't pursue fans as long as they don't go overboard with their adoration. Essentially, she said, that means: "as long as nobody crosses that line - either in bad taste or in profiting from the use of our characters." ... "At the end of the day this is about everybody just having fun with Star Wars," said Lucasfilm's Cole. "Go be creative" (Rodgers 2001).

20. Copyright-free material may, of course, be incorporated into copyrighted products. However, though encryption (or other use of code, such as the way that .pdf files can disallow copy-and-pasting of text), copyright-free material can be copy-disabled either by the fact of the encryption (if it should be difficult to decode) or by the legal protection of the encryption method itself (for such processes can be copyrighted and patented).

21. I refer to Monsanto's practice of licensing rather than selling seeds. The license includes permission for Monsanto inspectors to show up on the property at any time in order to ensure that seeds aren't being saved for replanting. Monsanto's 'terminator gene' project - cancelled due to public outcry - was an attempt to enforce this licensing requirement and the dependence produced thereby within the genetic code itself by making crops become infertile once sprayed with RoundUp, the only herbicide contractually allowed under the Monsanto license. Monsanto also donates GMO seed to third-world countries, teaching them non-sustainable farming techniques which make these farmers dependent upon Monsanto products and makes these farmers as well as their compatriots unable to sell to many European countries, whose laws often prohibit the importation of crops from countries growing genetically modified crops. This is then used by Monsanto as an example of philanthropy for public relations purposes.

22. "Software makers want businesses to buy their products the same way they purchase pens, staples, or automobiles--if you need cars for 10 workers, you buy 10 cars." (Jackson 2001) But this is true for members of the general public as well - for example,

There are several ways in which you might lift 
intellectual property from software makers. First, you can soft-lift - that is, buy one copy of, say, Microsoft Office and install it on your home office system, your laptop, even your kids' PC. You may also be guilty of LANlifting. That's when you purchase a single-user license for an application but load it on your LAN, giving every PC on the network access.

In addition, you might have a nasty habit of versionlifting. This is when you buy the same number of software packages as the number of PCs you own, but you only upgrade one or two programs and load the latest versions on all your computers. Think a few recent versions lying around the home office will insulate you from liability? You're wrong (Rothken 1998).

23.

Shrink-wrap contracts ... are the terms and conditions that accompany software distributed in a retail computer store. Shrink-wrap contracts usually read something like "By opening the packaging on this box you agree to the terms and conditions of the license." The terms and conditions of the license are more often than not located inside the box. ... Click-wrap contracts were developed in response to the massive growth of the Internet and Internet technology. A party enters into a clickwrap contract when they click the "I agree" or "I accept" button which are preceded by terms and conditions. Examples of where click-wrap contracts can be regularly seen include before you download software, before you book an airline ticket online, before you download music and many more (Callan 2005).

The legality of these types of contract remains in dispute. They may require all manner of waiver of fair use, and are usually long, complex, and difficult enough to find that few end users are aware of the limits of their use of purchased goods, leading to a chilling effect on fair use. There are further problems making true consent problematic, as, for example, that if one should open a shrinkwrap licensed product, one cannot return it to a retail location because they cannot accept returns of opened software boxes in order to prevent from copying the material. Such products must be returned directly to the manufacturer if one declines to accept the terms disclosed after purchase, and manufacturers may refuse to accept a return on the same basis, and even if accepted monetary recompense would be likely to take 8 to 10 weeks.

\section{As Lessig states the point,}

The real harm of term extension comes not from these famous works [e.g. Mickey Mouse, Rhapsody in Blue, the work of Robert Frost]. ... If you look at the work created in the first twenty years (1923 to 1942) affected by the Sonny Bono Copyright Term Extension Act, 2 percent of that work has any continuing commercial value. It was the copyright holders for that 2 percent who pushed the CTEA through. But the law and its effect were not limited to that 2 percent. The law extended the terms of copyright generally.

Think practically about the consequence of this extension ... In 1930, 10,047 books were published. In 2000, 174 of those books were still in print (2004: 221-2).

25. "[B]y the time the copyright for these films [viz. those among the earliest protected under the CTEA] expires, the film will have expired.... [N]itrate stock dissolves over time... the metal canisters in which they are now stored will be filled with nothing more than dust" (Lessig 2004:224-5).

26. "Felony penalties attach when the violation consists of the reproduction or distribution of at least ten copies that are valued together at more than $\$ 2,500$, or, under amendments enacted in 2005, when the violation involves distribution of a work being prepared for commercial distribution over a publicly-accessible computer network" (United States Department of Justice 2006).

\section{For example, consider this case from Lessig:}

In 1990, [Jon] Else was working on a documentary about Wagner's Ring Cycle. ... [In one scene] playing on the television set, while the stagehands played checkers and the opera company played Wagner, was The Simpsons. As Else judged it, this touch of cartoon helped capture the flavor of what was special about the scene.

Else then contacted Simpsons creator Matt Groening to clear permissions for the incidental use of copyrighted material, who said it was fine, but that he should clear it with the production company, Gracie Films. They were fine with the use as well, but told him to clear it with their parent company, Fox. "Then, as Else told me, "two things happened. First we discovered ... that Matt Groening doesn't own his own creation - or at least that someone [at Fox] believes he doesn't own his own creation." And second, Fox "wanted ten thousand dollars as a licensing fee for us to use this four-pointfive seconds of ... entirely unsolicited Simpsons which was in the corner of the shot."

Else was certain there was a mistake. He worked his way up to someone he thought was a vice president for licensing, Rebecca Herrera. He explained to her, "There must be some mistake here.... We're asking for your educational rate on this." That was the educational rate, Herrera told Else. A day or so later, Else called again to confirm what he had been told.

"I wanted to make sure I had my facts straight," he told me. "Yes, you have your facts straight," she said. It would cost $\$ 10,000$ to use the clip of The Simpsons in the corner of a shot in a documentary film about Wagner's Ring Cycle. And then, 
astonishingly, Herrera told Else, "And if you quote me, I'll turn you over to our attorneys" (Lessig 2004:95-6.)

\section{To be exact, the WIPO states:}

The mission of WIPO is to promote through international cooperation the creation, dissemination, use and protection of works of the human mind for the economic, cultural and social progress of all mankind. Its effect is to contribute to a balance between the stimulation of creativity worldwide, by sufficiently protecting the moral and material interests of creators on the one hand, and providing access to the socio-economic and cultural benefits of such creativity worldwide on the other (World Intellectual Property Organization 2004:5).

This reinforces the implication of the quote above, for it is stated that it is the work of the human mind that is to be protected rather than the rights of the author or inventor. Similarly, we see that the WIPO seems to equate stimulation of creativity worldwide with such closed-source protection, as in this passage from the same document:

WIPO increasingly does not stop short of promoting all kinds of intellectual property. This is only the means to achieve an end, which is to promote human creativity that results in industrial and cultural products and services enriching human society as a whole. Thus WIPO is increasingly involved in helping developing countries, whose creativity has yet to be adequately harnessed, to receive the full benefits of the creations of their citizens, as well as those of the outside world. WIPO's role is to assist them also in the preparation and enforcement of laws, in the establishment of sound institutions and administrative structures and in the training of appropriate personnel (2004:6).

This statement seems to imply that the WIPO will help developing countries by bringing in strong intellectual property rights, and by making developing countries into exporters of intellectual goods, which would admittedly be a welcome change from the historic and ongoing seizure and inappropriate recompense of the traditional and cultural knowledge and flora of peoples in developing nations. Nevertheless, it is not at all clear that strong intellectual property rights are in the best interests of developing nations, especially given the comparative difficulties in establishing a claim to compulsory licensing through WIPO or TRIPS, and, just as, in the quote above, it is inappropriate for the WIPO to assume that it is always in accord with the desires and interests of the author to impose exclusive rights, similarly it is inappropriate to assume that desires and interests of developing peoples are best served by signing on to a strong intellectual property regime. John Barton points out, for example, that "Devloped countries often proceed on the assumption that what is good for them is likely to be good for developing countries... [B]ut in the case of developing countries, more and stronger protection is not necessarily better," (Mantell 2002) and the report on Integrating Intellectual Property Rights and Development Policy from the Commission on Intellectual Property Rights strikes a note of caution:

Whether IPRs are a good or bad thing, the developed world has come to an accommodation with them over a long period. Even if their disadvantages sometimes outweigh their advantages, by and large the developed world has the national economic strength and established legal mechanisms to overcome the problems so caused. Insofar as their benefits outweigh their disadvantages, the developed world has the wealth and infrastructure to take advantage of the opportunities provided. It is likely that neither of these holds true for developing and least developed countries (Commission on Intellectual Property Rights 2002:6).

29. This collusion is not limited to cross-licensing or anti-competitive bundling; we can see a striking example in the possible loss of network neutrality, which loss would help exclude independently produced content from being able to effectively compete against commodified goods produced by the copyright industries.

\section{References}

Accra Mail. 2001. "Ghana: Microsoft to Conduct Raids on Pirates." www.africaonline.com. Accessed November 2, 2008 (http://web.archive.org/web/20031024025730/http://www. africaonline.com/site/Articles/1,3,43260.jsp).

Agent000. 2001. "A Visit from the Software Gestapo." www. kuro5in.org. Accessed November 2, 2008 (http://www. kuro5hin.org/story/2001/12/18/2042/8631).
Borland, John. 2002a. "Studios, RIAA Warn CEOs on File Trading." c|net news.com. Accessed November 2, 2007 (http://www.news.com/2100-1023-963208.html).

-----.2002b. "Hollywood Chases Down Campus Pirates." c|net news.com. Accessed November 2, 2007 (http://www.news. com/2100-1023-961637.html).

-----.2004. "MyTunes Source Code Lost." ZDNet.co.uk. Accessed May 1, 2008 (http://news.zdnet.co.uk/software/0,100000012 $1,39148139,00 \cdot \mathrm{htm})$. 
Bowman, Lisa M. 2001. "Broadband Fans Busted over Gnutella." c|net news.com. Accessed November 2, 2007 (http://www. news.com/2100-1023-255961.html).

-----.2002a. "ElcomSoft Verdict: Not Guilty." c|net news.com. Accessed November 2, 2007. (http://www.news.com/21001023-978176.html).

-----.2002b. "Navy Raids Student Pirates." ZDNet.co.uk. Accessed Nov. 2, 2007. (http://news.zdnet.co.uk/software/0,10000001 21,2126527,00.htm)

Buckman, Rebecca. 2000. "Microsoft Loads up for Pirate Raids." ZDNet.com. Accessed November 2, 2008 (http://news.zdnet. com/2100-9595_22-522676.html?legacy=zdnn).

Business Software Alliance. 2001. Nationwide Intensification of Raids on Illegal Software Users Begin in Kuala Lumpur. w3.bsa. org. Accessed November 2, 2007 (http://w3.bsa.org/malaysia/ press/newsreleases/Nationwide-Intensification-of-Raids-onIllegal-Software-Users-Begin-in-Kuala-Lumpur.cfm).

Callen, David. 2005. "How Click-Wrap Contracts Benefit over Shrink-Wrap Contracts." www.articleworld.net. Accessed Nov. 3, 2007 (http://www.articleworld.net/articles/45/1/ How-click-wrap-contracts-benefit-over-shrink-wrap-contracts).

Cohen, G. A. 1978. Karl Marx's Theory of History: A Defence. Princeton: Princeton University Press

Cohen, Yvan. 1997. "Software Pirates Pile Up Profits in Afflicted Asia. The Christian Science Monitor. Accessed November 2, 2007 (http://web.archive.org/web/20040103072948/search. csmonitor.com/durable/1997/12/29/intl/intl.1.html).

Comission on Intellectual Property Rights. 2002. "Executive Summary." In Integrating Intellectual Property Rights and Development Policy. www.iprcommission.org. Accessed November 3, 2007 (http://www.iprcommission.org/graphic/ documents/final_report.htm).

Contact Pakistan. 2001. "Raids Continue to Enforce Copyright Laws." www.contactpakistan.com. Accessed November 2, 2007 (http://www.contactpakistan.com/news/news148.htm).

Davidson, Paul. 2004. "Patents Out of Control?" www.usatoday. com. Accessed November 3, 2007 (http://www.usatoday.com/ money/companies/regulation/2004-01-13-patentscover_x. htm).

Drahos, Peter and John Braithwaite. 2003. Information Feudalism. New York: W.W. Norton.

Felten, Edward. "Reading Between the Lines: Lessons from the SDMI Challenge.”E-mail sent to sdmi-paper-info@ CS.Princeton.EDU, Apr. 2001. Archived on Cryptome.org. Accessed October 31, 2008 (http://cryptome.org/sdmi-attack.htm.).

Garaudy, Roger. 1970. The Crisis in Communism. Peter and Betty Ross trans. New York: Grove Press.

Jackson, Joab. 2001. “Justifying the Means.” www.citypaper.com. Accessed November 2, 2007 (http://www.citypaper.com/ columns/story.asp?id=5512).
Jefferson, Thomas. [1813] 2000. “Thomas Jefferson to Isaac McPherson, Monticello, August 13th, 1813.” press-pubs. uchicago.edu. Accessed October 31, 2007 (http://press-pubs. uchicago.edu/founders/documents/a1_8_8s12.html).

Lebihan, Rachel. 2001. "Australian Police Chastised for Warez Raids.” ZDNet.com.au. Accessed November 2, 2007 (http:// www.zdnet.com.au/news/security/soa/Australian-Policechastised-for-Warez-raids/0,130061744,120262446,00.htm).

Lessig, Lawrence. 2004. Free Culture: How Big Media Uses Technology and the Law to Lock Down Culture and Control Creativity. New York: Penguin.

Linux Online. 2001. "Linux Software DVD Player Now Available To Manufacturers." www.linux.org. Accessed November 3, 2007 (http://www.linux.org/news/2001/02/05/0002.html).

Love, Courtney. 2000. “Courtney Love Does the Math.” salon. com. Accessed Oct 31, 2007. (http://archive.salon.com/tech/ feature/2000/06/14/love/).

Manjoo, Farhad. 2001. "Were DrinkOrDie Raids Overkill?" wired.com. Accessed November 2, 2007 (http://www.wired. com/science/discoveries/news/2001/12/49096).

Mantell, Katie. 2002. "Patents Could Hinder Poverty Reduction." www.scidev.net. Accessed November 3, 2007 (http://www.scidev.net/News/index. $\mathrm{cfm}$ ?fuseaction $=$ readnews\&itemid $=141$ \&language $=1$ ).

Marx, Karl. 1932. "Part I: Feuerbach. Opposition of the Materialist and Idealist Outlook: A. Idealism and Materialism." In The German Ideology. www.marxists.org. Accessed November 3, 2007 (http://www.marxists.org/archive/marx/ works/1845/german-ideology/ch01a.htm).

-----.1959. “First Manuscript, Rent of Land." In Economic and Philosophical Manuscripts of 1844. M. Mulligan trans. www. marxists.org. Accessed November 3, 2007 (http://www. marxists.org/archive/marx/works/1844/manuscripts/rent. htm).

--.1996. Capital, Vol. I. Marx-Engels Collected Works, v. 35. New York: International Publishers.

-.1998. Capital, Vol. III. Marx-Engels Collected Works, v. 37. New York: International Publishers.

McCullagh, Declan. 2003. "ISP Appeals RIAA Song-Swapper Subpoena." ZDNet.co.uk. Accessed November 2. 2007 (http://news.zdnet.co.uk/internet/0,1000000097,2129666, 00.htm).

Microsoft South Africa. 2002. "Anti-Piracy Stakeholders Join Hands." www.microsoft.com. Accessed November 2, 2007 (http://web.archive.org/web/20031206133338/http://www. microsoft.com/southafrica/press/press-624.htm).

Miltrano, Tracy. 2002. "Important Information About Using the Cornell Network to File-Share and Download Music, Games and Videos: The Recreational Downloading of Copyrighted Materials is a Violation of Federal Law and University Policy." www.kuro5hin.org. Accessed November 2, 2007 (http://www. kuro5hin.org/story/2002/8/31/14253/3495). 
Motion Picture Association of America. 2000. "Re: Illegal Provision of DeCSS/Circumvention Device. Letter to Cryptome, John Young." cryptome.org. Accessed November 2, 2007 (http://cryptome.org/dvd-mpaa-ccd.htm).

Motion Picture Association of America. 2001. "Re: Unauthorized Distribution of Copyrighted Motion Pictures, Site/URL: http://www.cs.cmu.edu/ dst/" www.cs.cmu.edu. Accessed November 2, 2007 (http://www.cs.cmu.edu/ dst/DeCSS/ Gallery/mpaa-threat-feb2001.txt).

PC Gameworld.com. 2002. "Microsoft Raids Game Developer Offices." www.pcgameworld.com. Accessed November 2, 2007 (http://web.archive.org/web/20020705181228/http://www. pcgameworld.com/story.php/id/238/).

Perelman, Michael. 1998. Class Warfare in the Information Age. New York: Palgrave Macmillan.

-----.2002. Steal this Idea: Intellectual Property Rights and the Corporate Confiscation of Creativity. New York: Palgrave Macmillan.

Rodgers, Andrew. 2001. "Phantom Edit Deletes Jar Jar Binks." zap2it.com. Accessed November 3, 2007 (http://movies.zap2it. $\mathrm{com} / \mathrm{movies} /$ news/story/0,1259,---6903,00.html).
Rothken, Ira P. 1998. “Are You a Software Pirate?” www.techfirm. com. Accessed November 2, 2007 (http://www.techfirm.com/ newpage7.htm).

Stecklow, Steve. 2005. "Meet the 21-yr-Old Norwegian who Defied Hollywood." www.post-gazette.com. Accessed November 3, 2007 (http://www.post-gazette.com/ pg/05290/590139.stm).

Tsang, Susan. 2001. "Singapore Raids Net Pirated Windows XP." ZDNet.co.uk. Accessed November 2, 2007 (http://news. zdnet.co.uk/software/0,1000000121,2098919,00.htm).

United States Department of Justice, Computer Crime and Intellectual Property Section. 2006. "II. Criminal Copyright Infringement 17 U.S.C. 506 and 18 U.S.C. 2319,” in Prosecuting IP Crimes Manual, Third Edition. www.usdoj.gov. Accessed May 1, 2008 (http://www.usdoj.gov/criminal/cybercrime/ipmanual/02ipma.html).

World Intellectual Property Organization. 2004. WIPO Intellectual Property Handbook: Policy, Law and Use (WIPO Publication No.489 (E)). www.wipo.int. Accessed November 3, 2007 (http://www.wipo.int/about-ip/en/iprm/pdf/ch1. pdf). 
